\title{
Review
}

\section{A Mechanism of Antitumor Immunity Induced by Hyperthermia}

\author{
AKIRA ITO ${ }^{1}$, TAKESHI KOBAYASHI ${ }^{1+}$, HIROYUKI HONDA ${ }^{1 *}$ \\ ${ }^{1}$ Department of Biotechnology, School of Engineering, Nagoya University, \\ Furo-cho, Chikusa-ku, Nagoya 464-8603, Japan \\ 1+ (Present address: School of Bioscience and Biotechnology, Chubu University, \\ Matsumoto-cho 1200, Kasugai, Aichi 487-8501, Japan)
}

Key words: heat shock proteins, intracellular hyperthermia, magnetite, tumor immunity,

Abstract: Resent evidence is accumulating for the important role of heat shock proteins (HSPs), initiating immune responses for cancer. On the other hand, because expression of HSPs protects cells from heat-induced apoptosis, HSP expression has been considered to be a complicating factor in hyperthermia. If HSP expression induced by hyperthermia is involved in cancer immunity, novel cancer immunotherapy based on this novel concept can be developed. In such a strategy, a tumor-specific hyperthermia system would be highly advantageous, because, for conventional hyperthermia systems, it is difficult to induce necrotic cell death without damaging normal tissue because of the thermotolerance induced by HSPs. To achieve tumor-specific hyperthermia, an intracellular hyperthermia system using magnetite nanoparticles was developed. This novel hyperthermia system can induce necrotic cell death via HSP expression, which in turn induces antitumor immunity. In the present article, a mechanism of antitumor immunity caused by intracellular hyperthermia using magnetite nanoparticles is reviewed.

\section{Introduction}

"Quae medicamenta non sanat; ferrum sanat. Quae ferrum non sanat; ignis sanat. Quae vero ignis non sanat; insanabilia reportari oportet. Hippocrates."

(Those diseases which medicines do not cure, the knife cures; those which the knife cannot cure, fire cures; and those which fire cannot cure, are to be reckoned wholly incurable.)

As Hippocrates (460-370 BC) described in his aphorism, he believed that any diseases could be cured by heating patients' body. Thus, hyperthermia is a promising approach to cancer therapy. A major technical problem with hyperthermia is the difficulty of heating the local tumor region to the intended temperature without damaging normal tissue. Conventional hyperthermia systems are designed to heat tissue to around $42.5^{\circ} \mathrm{C}$ to $44.0^{\circ} \mathrm{C}$. However, higher temperatures can kill greater numbers of tumor cells, and in principle, tumor-specific hyperthermia can kill all kinds of tumor cells. 
Using magnetite nanoparticles, we have developed an intracellular hyperthermia system that achieves artificial local control of temperature within tumors in the human body. This hyperthermia treatment has produced unexpected biological responses, including overcoming thermotolerance due to specific heating of the tumor at high temperature, and an anti-tumor immune response induced by expression of heat shock proteins (HSPs). These results suggest that our hyperthermia system can kill not only heated tumors but also non-heated tumors, including metastatic cancer cells. We have investigated the role of HSP70, in order to elucidate the mechanism of immune induction by hyperthermia ${ }^{12}{ }^{2}$. We discussed here a mechanism of the anti-cancer immune response induced by our intracellular hyperthermia using magnetite nanoparticles.

\section{Intracellular hyperthermia using magnetite nanoparticles}

Various heating methods have been applied in hyperthermia, including the use of hot water, capacitive heating and inductive heating ${ }^{3-5)}$. However, an inevitable technical problem with hyperthermia is the difficulty of uniformly heating only the tumor region to the required temperature without damaging normal tissue. Accordingly, some researchers have proposed the use of intracellular hyperthermia to achieve "tumor-specific hyperthermia system", and have developed submicron magnetic particles for this purpose ${ }^{6)}{ }^{7}$. Intracellular hyperthermia is based on the principle that a magnetic particle can generate heat by hysteresis loss under an alternating magnetic field (AMF). In 1979, Gordon et al first proposed the concept of intracellular hyperthermia using dextran magnetite $\left(\mathrm{Fe}_{3} \mathrm{O}_{4}\right)$ nanoparticles ${ }^{8}$. We have used drug delivery system (DDS) techniques to develop antibody-conjugated liposomes (immunoliposomes) containing magnetite nanoparticles (antibody-conjugated magnetoliposomes, AMLs; Fig.1). We constructed immunoliposomes using mouse G22 monoclonal antibody (MAb) against human glioma cells ${ }^{9}$, mouse G250 MAb against human renal cell carcinomas ${ }^{10)}$ and humanized MAb against human epidermal growth factor receptor-2 (Herceptin $\left.{ }^{\circledR}\right)^{11}$, and demonstrated the tumor-specific targeting ability of these immunoliposomes. Also, accumulation of magnetite nanoparticles in tumor cells can be enhanced by conferring a positive surface charge to liposomes. We

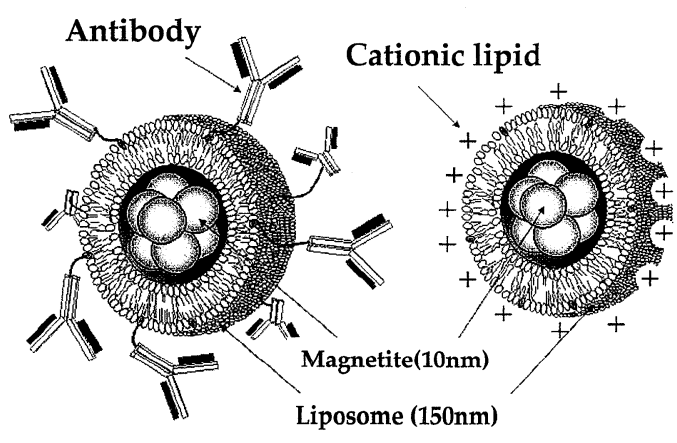

Antibody-conjugated magnetoliposome (AML)

Fig. 1. Liposomal drugs containing magnetite nanoparticles for DDS. have developed "magnetite cationic liposomes (MCLs ; Fig.1)" with improved adsorption and accumulation properties. MCLs, which have a positive surface charge, have ten-fold higher affinity for glioma cells than neutrally charged magnetoliposomes ${ }^{12)}$. We demonstrated the efficacy of hyperthermia using magnetite nanoparticles in animals with several types of tumor, including B16 mouse melanoma ${ }^{13)}$, MM46 mouse mammary carcinoma ${ }^{14)}, \mathrm{T}-9$ rat glioma ${ }^{15)}$, Os515 hamster osteosarcoma ${ }^{16)}, \mathrm{VX}-7$ squamous cell carcinoma in rabbit tongue ${ }^{17)}$, PLS 10 rat prostate cancer (unpublished result), and PC3 and LNCaP human prostate cancer in nude mice 

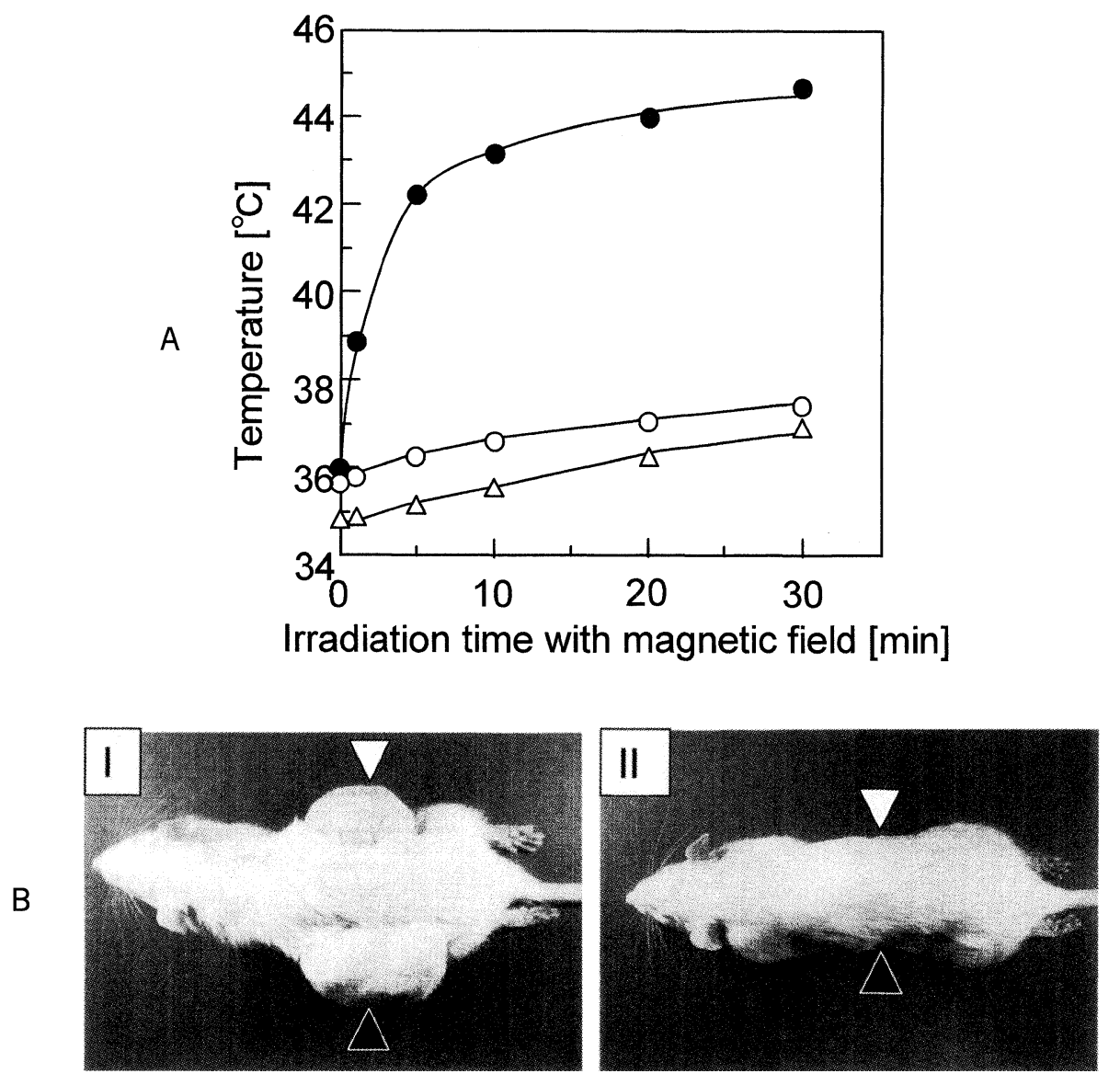

Fig. 2. Anti-cancer immune response induced by hyperthermia using magnetite nanoparticles. Rats bearing tumors on each side of the body were prepared. MCLs were injected into the left tumor only, and the rats were irradiated with an alternating magnetic field (AMF). A) Temperature of left tumor, containing MCLs (closed circles), increased specifically, whereas temperature of right tumor (open circles) and rectum (open triangles) remained below $37^{\circ} \mathrm{C}$. B) The tumor-specific hyperthermia treatment induced an anti-tumor immune response, and both tumors had disappeared on the $28^{\text {th }}$ day after hyperthermia treatment. I) Control rat without AMF irradiation; II) rat with AMF irradiation. Open triangles in $B$, the side without MCLs; closed triangle in $B$, the side with MCLs.

(unpublished results).

We observed antitumor immune response induced by hyperthermia using MCLs in an experimental T-9 rat glioma model in which a tumor was transplanted into each femur of a rat (Fig.2) ${ }^{18)}$. Interestingly, although only one tumor was subjected to hyperthermia, the other tumor also disappeared completely. Immunohistochemical assay revealed that NK cells and CD8- and CD4-positive T cells migrated into the tumors after the hyperthermia treatment ${ }^{18)}$. These results suggest that the therapeutic magnetite nanoparticles are potentially effective tools for hyperthermia, because in addition to killing tumor cells with heat, they induce a host immune response. As a mechanism for recognition of tumor antigens by the host immune system, we have proposed heat shock protein (HSP) -mediated antitumor immunity. 


\section{Augmentation of tumor immunogenicity by hyperthermia}

HSPs, which are abundant intracellular proteins, function as molecular chaperons that control the folding and prevent the aggregation of proteins ${ }^{19)}$. Because expression of HSPs protects cells from heat-induced apoptosis ${ }^{20)}$, HSP expression has been considered a complicating factor in hyperthermia. Because hyperthermia is a physical treatment, it is likely to have fewer side effects than chemotherapy. Consequently, an advantage of hyperthermia is the feasibility of frequent repeated treatment ${ }^{14)}$. However, conventional hyperthermia systems involve treatment only once or twice per week, performed at an interval of more than $48 \mathrm{~h}$, to prevent thermotolerance ${ }^{21,22)}$ caused by HSP expression.

On the other hand, recent reports have shown the importance of HSPs in immune reactions, including HSP70, HSP90 and glucose-regulated protein 96, and studies suggest that HSPs chaperon tumor antigens ${ }^{23-25)}$. With regard to the mechanism of antitumor immunity induced by hyperthermia using MCLs, our findings suggest two possible mechanisms of antigen presentation via HSP70 expression during hyperthermia ${ }^{12)}$. One possible mechanism is heat-induced augmentation of tumor immunogenicity due to presentation of antigenic peptides via MHC class I antigens of tumor cells. Srivastava et al. proposed the following "relay line model" for tumor antigenic peptide transfer during antigen processing and presentation by HSPs ${ }^{26-28)}$. 1) The peptides are first bound to HSP70 or HSP90, which carry them to the endoplasmic reticulum (ER) via the transporter associated with antigen processing (TAP). 2) The peptides are transferred to gp96 in the lumen of the ER. 3) In the terminal step, gp96 transfers the peptides to the MHC class I $-\beta_{2}$ microglobulin complexes. Wells et al. demonstrated that stably transfected B16 melanoma cells that constitutively expressed human HSP70 exhibited significantly increased levels of MHC class I antigens on their surface ${ }^{29)}{ }^{30)}$. We have shown that augmentation of MHC class I antigens on the tumor cell surface via HSP70 expression causes immune induction ${ }^{1)}$. The working hypothesis is illustrated in Fig.3. In that study, HSP70 expression reached its maximum $24 \mathrm{~h}$ after heating, and the augmentation of MHC class I surface expression began $24 \mathrm{~h}$ after heating and reached its maximum $48 \mathrm{~h}$ after heating. The expression of other immunologic mediators, such as intracellular adhesion molecule-1 (ICAM-1) and MHC class II, did not increase. In an in vivo experiment, growth of T-9 cells in immunocompetent syngenic rats (F344) was significantly inhibited by hyperthermia, with augmentation of MHC class I antigen surface expression, whereas growth of T-9 cells was not inhibited in nude rats, suggesting that the effector cells were $\mathrm{T}$ lymphocytes. Furthermore, compared with lymphocytes from non-immunized rats or rats injected with non-heated T-9 cells, the splenic lymphocytes of rats injected with heated T-9 cells displayed specific cytotoxicity against T-9 cells. Okamoto et al. ${ }^{31)}$ reported that immunization of mice with heat-treated colon-26 cell extract, which was enriched in HSP70, elicited antitumor immunity against subcutaneously injected colon-26 cells. Also, similar immunization enhanced the cytotoxic activity of mouse splenic lymphocytes against heat treated colon-26 cells. Because cell extracts contained various antigens, HSP-independent antigens may be also involved in the antitumor immunity. However, these results suggest that HSP70 is an important modulator of tumor cell immunogenicity during hyperthermia, and that cytotoxic T-lymphocytes (CTLs) are the effector cells. 


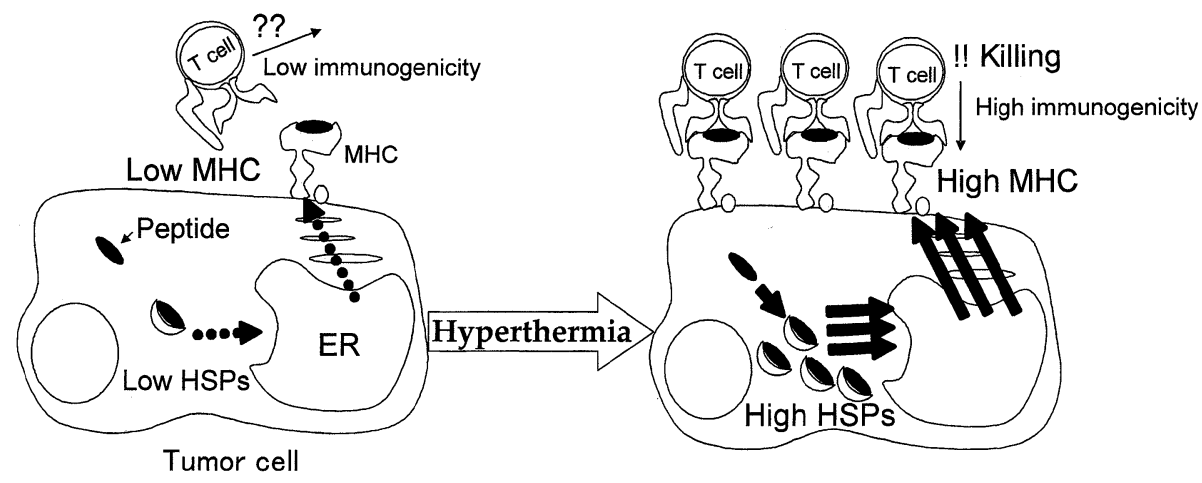

Fig. 3. Augmentation of tumor immunogenicity by an increase of the number of MHC molecules on the surface of cancer cells via inducible HSP expression during hyperthermia.

\section{Vaccine-like effect of HSP-peptide complex released from necrotic cells during hyperthermia}

An alternative mechanism of recognition of tumor antigens by the host immune system in hyperthermia is cross-presentation of antigenic peptides by dedicated antigen-presenting cells (APCs), including dendritic cells (DCs). The working hypothesis is illustrated in Fig.4. HSP-mediated antitumor immunity may be caused by a vaccine-like effect of HSP-peptide complexes released from dying tumor cells. The released HSP-peptide complexes encounter APCs that express receptors such as CD91 ${ }^{32}$, $\mathrm{CD} 40^{33)}$ and Toll-like receptors $2 / 4^{34)}$. Interaction of HSP-peptide complexes with these receptors leads to receptor-mediated endocytosis, processing of the antigenic peptide by the endogenous MHC class I pathway, and re-presentation on the cell surface to CD8-positive T cell receptors. Additionally, HSP70 functions as a direct activator of APCs, stimulating cytokine secretion from monocytes and inducing the maturation of DCs via CD14 and/or CD91 receptors ${ }^{35}$ ). This cytokine-like ability of HSP70 to stimulate the innate immune system is independent of the peptides they chaperone, suggesting that HSP70 is a natural adjuvant ${ }^{36)}$ 37).

Classical immunology theory is based on the distinction between "self and nonself". However, this self-nonself model is sometimes not very useful, particularly in cancer immunity because cancer

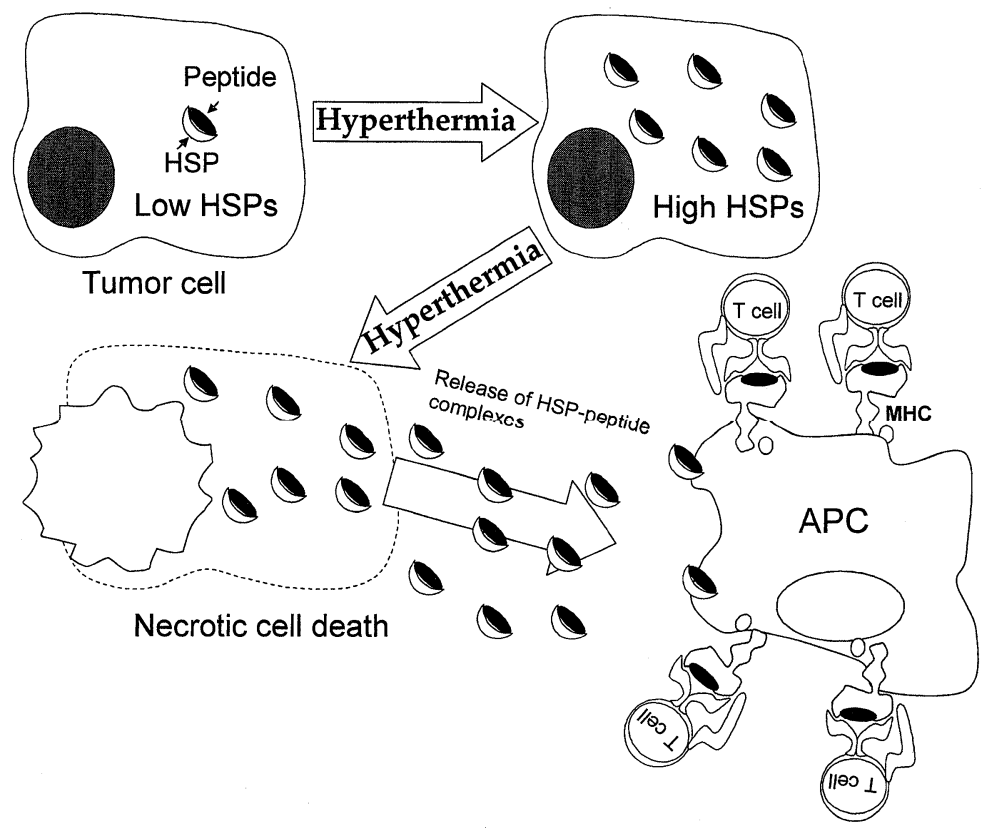

Fig. 4. Mechanism of anti-cancer immune induction by hyperthermia. In situ vaccination by HSP-peptide complexes released from dying cells via necrosis by hyperthermia treatment 
cell is derived from normal cell that is "self" originally. Matzinger proposed the "Danger model", which suggests that the immune system is more concerned with damage than with foreignness ${ }^{38)}$. In the "Danger model", HSPs are considered an important "Danger signal". In particular, when HSPs, which are stress-indicators and normally present in cytoplasm, are released into the bloodstream, they can act as a signal to the immune system of an abnormal situation. We demonstrated that HSP70 expression following hyperthermia using MCLs induced antitumor immunity in rats with T-9 rat glioma ${ }^{18)}$. Because MCLs are themselves heated in our hyperthermia system, the distribution of magnetite nanoparticles within tumors is an important issue. When MCLs were repeatedly heated, the surrounding tumor tissues underwent necrosis, and magnetite nanoparticles subsequently expanded into the necrosis area within the tumor, resulting in wide distribution of magnetite nanoparticles. Thus, the entire tumor area was necrosed by repeated ( 3 times) hyperthermia (with a 24-h interval over 3 days) ${ }^{2}$. The 24-h interval corresponded to the time when HSP70 expression in T-9 cells reached its maximum, and a large amount of HSP70 was detected in the tumor tissue. Thus, our hyperthermia system using MCLs overcame thermotolerance and induced necrotic cell death that correlated with HSP70 expression. A reason why necrotic cell death via HSP70 expression is effective for cancer therapy is that necrotic cell death may strongly induce a "Danger signal". We observed that numerous and diverse kinds of immunocytes, such as CD8- and CD4-positive T-cells, NK cells, macrophages and DCs, infiltrated into the necrotic area of tumors after hyperthermia treatment ${ }^{2)}{ }^{18}$ ). Todryk et al observed infiltration of such cells into B16 melanoma nodules transfected with the HSP70 gene ${ }^{39)}$, suggesting that HSP70 expression is a "Danger signal" for recruitment of immunocytes. Next, we purified the HSP70-peptide complexes from the tumor after hyperthermia, and found that immunization of rats with T-9 HSP70 strongly suppressed tumor growth ${ }^{2)}$. HSP70-peptide complexes from liver were also purified, and their vaccine-like effects were examined, but no anti-tumor effects were observed. These results suggest that HSP70 in tumor cells chaperons some antigenic peptides after hyperthermia. Also, in order to investigate the vaccine-like effect of the tumor cells killed via hyperthermia-induced necrosis in rats, a tumor rejection assay was performed after hyperthermia treatment of implanted T-9 cells; tumor growth was strongly suppressed, and 50\% of the rats were protected from challenge with T-9 cells.

Recently, a vaccine consisting of autologous tumor-derived gp96-peptide complexes (HSPPC-96, Oncophage; Antigenics, Inc, Woburn, MA) has entered clinical trials, and the feasibility of its use to treat metastatic melanoma patients has been demonstrated ${ }^{40}$. Because HSP-peptide complexes must be extracted from tumors in the body, surgery is needed in this therapeutic protocol. In contrast, in hyperthermia using MCLs, no surgery or extraction is necessary. Udono et al. reported that the vaccination effect of HSP70-peptide complexes was directly dependent on the dose ${ }^{41}$. The HSPs in the tumor can be regarded as an antigen source, and $1 \mathrm{~g}$ (approximately $10^{8}$ cells) of tumor tissue may contain approximately $2 \mathrm{mg} \mathrm{HSP70.} \mathrm{This} \mathrm{represents} \mathrm{a} \mathrm{much} \mathrm{higher} \mathrm{dose} \mathrm{than} \mathrm{that} \mathrm{used} \mathrm{for} \mathrm{the} \mathrm{clinical} \mathrm{trials.} \mathrm{In}$ our hyperthermia system, the expression of HSP70 was enhanced, and tissue lysis via necrosis was observed throughout the tumor. Our hyperthermia system using MCLs can produce HSP-peptide complexes (possibly including HSPs such as HSP90 and gp 96), resulting in vaccination.

These results suggest that our hyperthermia system confers antitumor immunity via release of HSP70-peptide complexes during necrotic tumor cell death in vivo. This phenomenon, which may be 
called in situ vaccination, has important implications for development of novel anti-tumor therapies.

\section{Conclusion}

A proposed scenario in which HSPs function during successive stages of an antitumor response after hyperthermia is summarized and illustrated in Fig.5: 1) A poorly immunogenic tumor cell with a low concentration of intracellular HSP-peptide complexes, decreased function of the endogenous antigen processing machinery, and a very low level of MHC class I-peptide complexes at the cell surface. 2) A sublethal stress response induced by hyperthermia using MCLs results in increased levels of intracellular HSP-peptide complexes, enhanced processing of endogenous antigens, and an increase in the density of MHC class I-peptide complexes at the cell surface. These tumor cells are then recognized directly by MHC class I-restricted CTLs. 3) Dying tumor cells, which are killed by the CTLs or by lethal hyperthermia treatment, release their intracellular contents, including HSP-peptide complexes. 4) The released HSPs and/or antigenic peptides activate neighboring monocytes to produce proinflammatory cytokines and recruit APCs. 5) The HSP-peptide complexes are taken up by DCs, and are in turn presented to T cells via MHC class I and/or II antigens (cross-priming).

The mechanism of antitumor immune response induced by hyperthermia was studied by using T-9 rat glioma cells that are known to show relatively high immunogenicity. Currently, we use oncogene $R E T$-transgenic mice ${ }^{42)}$ in order to investigate whether the antitumor immunity can be induced in the mice in which melanoma spontaneously develops, as a hereditary melanoma model of low immunogenicity. Several melanoma nodules spontaneously developed in a RET-transgenic mouse in 3 month after birth. Interestingly, although only one tumor was subjected to hyperthermia, some of the

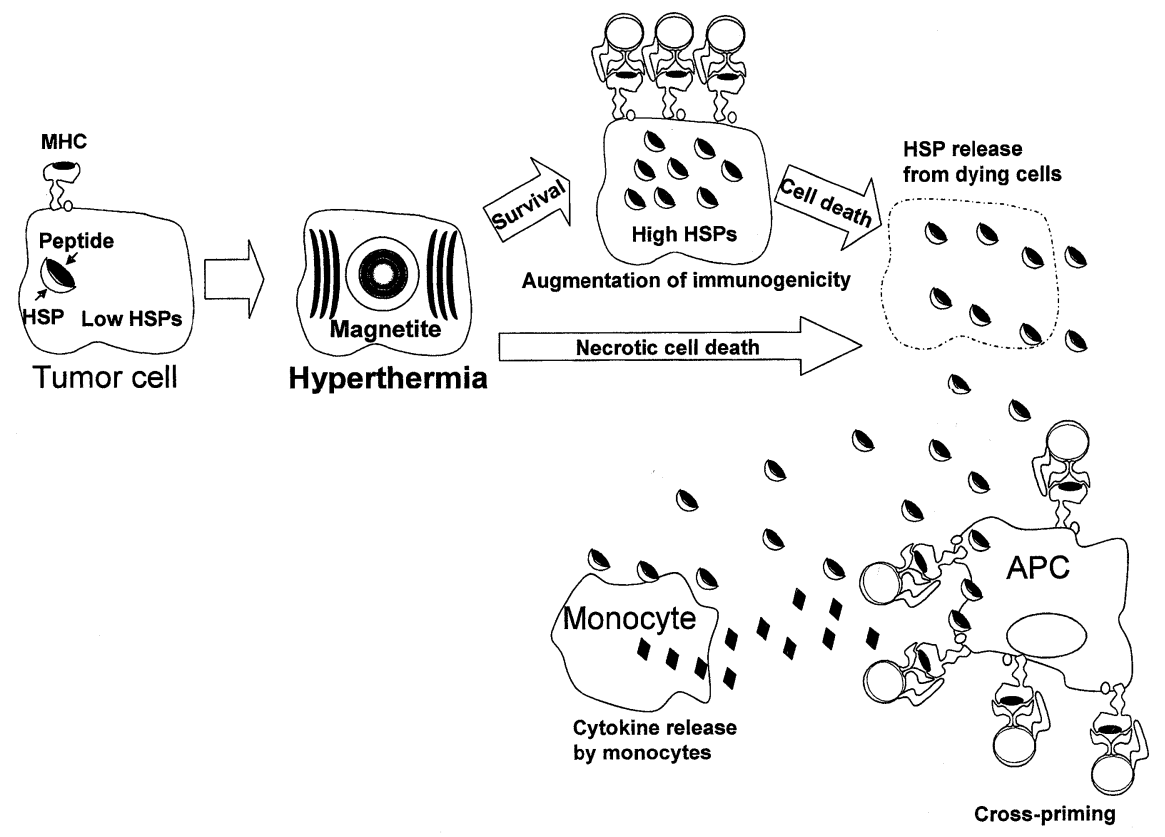

Fig. 5. Proposed scenario of the mechanism of anti-cancer immune induction by hyperthermia. 
other tumors ( $3 / 7$ tumors in a mouse) also disappeared completely (unpublished results). Further investigations to elucidate the mechanisms are ongoing.

We are currently developing novel cancer immunotherapy based on the mechanism of anti-cancer immune response via HSP expression. Three key elements may be involved in this mechanism : 1) CTL as an effector cell, 2) APC as an antigen-processing and -presenting cell for HSP-peptide complex released from necrotic cells, 3) HSPs as a natural and powerful immunostimulant. This strategy is based on combinations of hyperthermia using MCLs with cytokines (IL-2 and GM-CSF ${ }^{43}$ ), heat-inducible TNF- $\alpha$ gene therapy ${ }^{44)}$, recombinant HSP70 ${ }^{45)}$, HSP70 gene therapy ${ }^{46)}$, and DC therapy (unpublished results). We are conducting further studies to establish a novel cancer immunotherapy based on the concept of heat-controlled necrosis with HSP expression.

Acknowledgements This work was partly supported by Grants-in-Aid for Scientific Research (No. 13853005), University Start-Ups Creation Support System, and the $21^{\text {st }}$ Century COE Program "Nature-Guided Materials Processing" from the Ministry of Education, Culture, Sports, Science, and Technology of Japan.

\section{References}

1) Ito A., Shinkai M., Honda H., Wakabayashi T., Yoshida J., Kobayashi T. : Augmentation of MHC class I antigen presentation via heat shock protein expression by hyperthermia. Cancer Immunol Immunother, 50 : 515-522, 2001.

2) Ito A., Shinkai M., Honda H., Yoshikawa K., Saga S., Wakabayashi T., Yoshida J., Kobayashi T. : Heat shock protein 70 expression induces antitumor immunity during intracellular hyperthermia using magnetite nanoparticles. Cancer Immunol Immunother, 52: 80-88, 2003.

3) Cavaliere R., Ciocatto E. C., Giovanella B. C., Heidelburger C., Jonson R. O., Margottini M., Mondovi B., Moricca B. G., Rossi-Fanelli A. : Selective heat sensitivity of cancer cells. Biochemical and clinical studies. Cancer, 20 : 1351-1381, 1967.

4) Ikeda N., Hayashida O., Kameda H., Ito H., Matsuda T. : Experimental study on thermal damage to dog normal brain. Int J Hyperthermia, 10 : 553-561, 1994.

5) Stauffer P. R., Cetas T. C., Fletcher A. M., DeYoung D. W., Dewhirst M. W., Oleson J. R., Roemer R. B. : Observations on the use of ferromagnetic implants for inducing hyperthermia. IEEE Trans Biomed Eng, 31: 76-90, 1984.

6) Jordan A., Wust P., Fahling H., John W., Hinz A., Felix R.: Inductive heating of ferrimagnetic particles and magnetic fluids: physical evaluation of their potential for hyperthermia. Int J Hyperthermia, 9: 51-68,1993.

7) Moroz P., Jones S. K., Gray B. N. : Magnetically mediated hyperthermia : current status and future directions. Int J Hyperthermia, 18: 267-284, 2002.

8) Gordon R. T., Hines J. R., Gordon D. : Intracellular hyperthermia. A biophysical approach to cancer treatment via intracellular temperature and biophysical alterations. Med Hypothesis, $5:$ 83-102, 1979.

9) Le B., Shinkai M., Kitade T., Honda H., Yoshida J., Wakabayashi T., Kobayashi T. : Preparation of tumor-specific magnetoliposomes and their application for hyperthermia. J Chem Eng Jpn, 34 : 66-72, 2001.

10) Shinkai M., Le B., Honda H., Yoshikawa K., Shimizu K., Saga S., Wakabayashi T., Yoshida J., Kobayashi T. : Targeting hyperthermia for renal cell carcinoma using human MN antigen-specific magnetoliposomes. Jpn J Cancer Res, 92: 1138-1145, 2001.

11) Ito A., Kuga Y., Honda H., Kikkawa H., Horiuchi A., Watanabe Y., Kobayashi T. : Magnetite nanoparticle-loaded 
Antitumor immunity induced by Hyperthermia $\cdot$ A. Ito et al.

anti-HER2 immunoliposomes for combination of antibody therapy with hyperthermia. Cancer Lett, 212: 167-175, 2004.

12) Shinkai M., Yanase M., Honda H., Wakabayashi T., Yoshida J., Kobayashi T.: Intracellular hyperthermia for cancer using magnetite cationic liposome: in vitro study. Jpn J Cancer Res, 87 : 1179-1183, 1996.

13) Suzuki M., Shinkai M., Honda H., Kobayashi T. : Anticancer effect and immune induction by hyperthermia of malignant melanoma using magnetite cationic liposomes. Melanoma Res, 13: 129-135, 2003.

14) Ito A., Tanaka K., Honda H., Abe S., Yamaguchi H., Kobayashi T. : Complete regression of mouse mammary carcinoma with a size greater than $15 \mathrm{~mm}$ by frequent repeated hyperthermia using magnetite nanoparticles. J Biosci Bioeng, 96 : 364-369, 2003.

15) Yanase M., Shinkai M., Honda H., Wakabayashi T., Yoshida J., Kobayashi T. : Intracellular hyperthermia for cancer using magnetite cationic liposome: an in vivo study. Jpn J Cancer Res, 89: 463-469,1998.

16) Matsuoka F., Shinkai M., Honda H., Kubo T., Sugita T., Kobayashi T.: Hyperthermia using magnetite cationic liposomes for hamster osteosarcoma. Biomagn Res Technol, 2: 3, 2004.

17) Matsuno H., Tohnai I., Mitsudo K., Hayashi Y., Ito M., Shinkai M., Kobayashi T., Yoshida J., Ueda M. : Interstitial hyperthermia using magnetite cationic liposomes inhibit to tumor growth of VX-7 transplanted tumor in rabbit tongue. Jpn J Hyperthermic Oncol, 17: 141-149, 2001.

18) Yanase M., Shinkai M., Honda H., Wakabayashi T., Yoshida J., Kobayashi T. : Antitumor immunity induction by intracellular hyperthermia using magnetite cationic liposomes. Jpn J Cancer Res, 89: 775-782, 1998.

19) Lindquist S.: The heat-shock response. Ann Rev Biochem, 55 : 1151-1191, 1986.

20) Mosser D. D., Caron A. W., Bourget L., Meriin A. B., Sherman M. Y., Morimoto R. I., Massie B. : The chaperon function of hsp 70 is required for protection against stress-induced apoptosis. Mol Cell Biol, 20: 7146-7159, 2000.

21) Subjeck J. R., Sciandra J. J., Chao C. F., Johnson R. J. : Heat shock proteins and biological response to hyperthermia. Br J Cancer, 45 : 127-131, 1982.

22) Subjeck J. R., Sciandra J. J., Johnson R. J. : Heat shock proteins and thermotolerance ; a comparison of induction kinetics. Br J Radiol, 55 : 579-584, 1982.

23) Menoret A., Chandawarkar R.: Heat-shock protein-based anticancer immunotherapy: An idea whose time has come. Sem Immunol, $25:$ 654-660, 1998.

24) Srivastava P. K., Menoret A., Basu S., Binder R., Quade K. : Heat shock proteins come of age : primitive functions acquired new roles in an adaptive world. Immunity, 8: 657-665, 1998.

25) Tamura Y., Sato N.: Heat shock proteins : chaperoning of innate and adaptive immunities. Jpn J Hyperthermic Oncol, $19:$ 131-139, 2003.

26) Srivastava P. K., Maki R. G.: Stress-induced proteins in immune response to cancer. Curr Top Microbiol Immunol, $167:$ 109-123, 1991.

27) Srivastava P. K., Heike M.: Tumor-specific immunogenicity of stress-induced proteins: convergence of two evolutionary pathways of antigen presentation? Semin Immunol, 3: 57-64, 1991.

28) Srivastava P. K., Udono H., Blachere N. E., Li Z. : Heat shock proteins transfer peptides during antigen processing and CTL priming. Immunogenetics, 39: 93-98, 1994.

29) Wells A. D., Rai S. K., Salvato M. S., Band H., Malkovsky M. : Hsp72-mediated augmentation of MHC class I surface expression and endogenous antigen presentation. Int Immunol, 10: 609-617, 1998.

30) Wells A. D., Malkovsky M. : Heat shock proteins, tumor immunogenicity and antigen presentation : an integrated view. Immunol Today, $21:$ 129-132, 2000.

31) Okamoto M., Tazawa K., Kawagoshi T., Maeda M., Honda T., Sakamoto T., Tsukada K.: The combined effect against colon-26 cells of heat treatment and immunization with heat treated colon-26 tumour cell extract. Int $\mathrm{J}$ Hyperthermia, $16: 263-273,2000$. 
32) Basu S., Binder R. J., Ramalingam T., Srivastava P. K. : CD91 is a common receptor for heat shock proteins gp96, hsp90, hsp70, and calreticulin. Immunity, 14 : 303-313, 2001.

33) Becker T., Hartl F. U., Wieland F.: CD40, an extracellular receptor for binding and uptake of Hsp70-peptide complexes. J Cell Biol, 158: 1277-1285, 2002.

34) Asea A., Rehli M., Kabingu E., Boch J. A., Bare O., Auron P. E., Stevenson M. A., Calderwood S. K. : Novel signal transduction pathway utilized by extracellular HSP70: role of toll-like receptor (TLR) 2 and TLR4. J Biol Chem, 277: 15028-15034, 2002.

35) Asea A., Kraeft S. K., Kurt-Jones E. A., Stevenson M. A., Chen L. B., Finberg R. W., Koo G. C., Calderwood S. K. : HSP70 stimulates cytokine production through a CD14-dependent pathway, demonstrating its dual role as a chaperon and cytokine. Nat Med, 6: 435-442, 2000.

36) Srivastava P. K. : Roles of heat-shock proteins in innate and adaptive immunity. Nat Rev Immunol, 2 : 185-194, 2002.

37) Srivastava P. K. : Interaction of heat shock proteins with peptides and antigen presenting cells : chaperoning of the innate and adaptive immune responses. Annu Rev Immunol, 20 : 395-425, 2002.

38) Matzinger P.: The danger model : a renewed sense of self. Science, 296:301-305, 2002.

39) Todryk S., Melcher A. A., Hardwick N., Linardakis E., Bateman A., Colombo M. P., Stoppacciaro A., Vile R. G. : Heat shock protein 70 induced during tumor cell killing induces Th1 cytokines and targets immature dendritic cell precursors to enhance antigen uptake. J Immunol, 163: 1398-1408, 1999.

40) Belli F., Testori A., Rivoltini L., Maio M., Andreola G., Sertoli M. R., Gallino G., Piris A., Cattelan A., Lazzari I., Carrabba M., Scita G., Santantonio C., Pilla L., Tragni G., Lombardo C., Arienti F., Marchiano A., Queirolo P., Bertolini F., Cova A., Lamaj E., Ascani L., Camerini R., Corsi M., Cascinelli N., Lewis J. J., Srivastava P., Parmiani G.: Vaccination of metastatic melanoma patients with autologous tumor-derived heat shock protein gp96-peptide complexes : clinical and immunologic findings. J Clin Oncol, 20: 4169-4180, 2002.

41) Udono H., Srivastava P. K. : Comparison of tumor-specific immunogenicities of stress-induced protein gp 96 , hsp90, and hsp70. J Immunol, 152: 5398-5403, 1994.

42) Kato M., Takahashi M., Akhand A. A., Liu W., Dai Y., Shimizu S., Iwamoto T., Suzuki H., Nakashima I.: Transgenic mouse model for skin malignant melanoma. Oncogene, 17, 1885-1888, 1998.

43) Ito A., Tanaka K., Kondo K., Shinkai M., Honda H., Matsumoto K., Saida T., Kobayashi T. : Tumor regression by combined immunotherapy and hyperthermia using magnetic nanoparticles in an experimental subcutaneous murine melanoma. Cancer Sci, $94:$ 308-313, 2003.

44) Ito A., Shinkai M., Honda H., Kobayashi T. : Heat-inducible TNF-alpha gene therapy combined with hyperthermia using magnetic nanoparticles as a novel tumor-targeted therapy. Cancer Gene Ther, 8 : 649-654, 2001.

45) Ito A., Matsuoka M., Honda H., Kobayashi T. : Anititumor effects of combined therapy of recombinant heat shock protein 70 and hyperthermia using magnetic nanoparticles in an experimental subcutaneous murine melanoma. Cancer Immunol Immunother, 53 : 26-32, 2004.

46) Ito A., Matsuoka M., Honda H., Kobayashi T. : Heat shock protein 70 gene therapy combined with hyperthermia using magnetic nanoparticles. Cancer Gene Ther, 10: 918-925, 2003. 


\title{
ハイパーサーミアによる腫瘍免疫賦活のメカニズム
}

\author{
井藤彰・小林猛・本多裕之 \\ 名古屋大学大学院工学研究科化学・生物工学専攻
}

\begin{abstract}
要 旨: 近年, 腫瘍免疫における熱ショック蛋白質 (HSP) の役割が注目されている.一方, HSP は 温熱耐性を示寸因子として, ハイパーサーミアにおいてはデメリットとして考えられてきた。もし，ハイ パーサーミアにいけるHSP 発現が腫瘍免疫賦活に関与するのなら, HSP 発現を積極的に利用すると いった新しい概念に則った新しいガン免疫療法が開発できる.本稿では, ハイパーサーミアに伴う免疫賦 活のメカニズムについて, HSP に注目して述べる.
\end{abstract}

